\title{
MAKNA SIMBOLIK TRADISI SEDEKAH BUMI DI DESA MEDANI KECAMATAN CLUWAK KABUPATEN PATI
}

\author{
Heri Susanto ${ }^{1}$, Situ Asih ${ }^{2}$, Marjianto ${ }^{3}$ \\ Sekolah Tinggi Agama Buddha Negeri Raden Wijaya Wonogiri Jawa Tengah ${ }^{1,2,3}$ \\ herisuu02@gmail.com ${ }^{1}$ \\ situasih@yahoo.co.id ${ }^{2}$ \\ antonmarjianto@gmail.com ${ }^{3}$
}

\begin{abstract}
Sedekah Bumi tradition is one of rituals traditional society in Java that has been going for generations from the ancestors' Javanese people. The purpose of this study is to describe the process implementation of Sedekah Bumi Tradition, it carryout by society of Medani, Cluwak Pati. This research was a descriptive qualitative research. Data collection methods were through observation, interviews, and documentation, and the technique of validity the data through triangulation techniques. The location of this research is in Medani, Cluwak, Pati. This research was carried out from March to August 2021. Several processions are carried out in Sedekah Bumi Tradition (kabumi), namely Manganan, Kondangan, Mbangun tumbal, art and closings. The results of this study shows that the symbols that exist in Sedekah Bumi tradition as a tribute to the almighty. The symbolic meanings in Sedekah Bumi is interpreting human nature and teach virtue. The relevance of Sedekah Bumi tradition in Buddhism is existence of moral values as contained in the Buddhist' Pancasila, harmony and love.
\end{abstract}

Keywords: Symbolic Meaning, Tradition, Sedekah bumi

\section{PENDAHULUAN}

Indonesia merupakan negara yang multikultural, selain terdapat beragam jenis ras, agama, bahasa dan suku Bangsa. Selain itu Indonesia memiliki beragam jenis adat dan tradisi yang berbeda-beda di setiap daerahnya. Masing-masing daerah memiliki tradisi dan adat yang menunjukkan identitas dari daerah tersebut. Salah satu suku di Indonesia yang masih tetap melaksanakan berbagai macam tradisi sampai saat ini adalah masyarakat Jawa. Masyarakat Jawa merupakan masyarakat yang kaya akan berbagai macam tradisi. 
Pada umumnya tradisi-tradisi masyarakat Jawa tersebut berupa upacara-upacara selamatan yang berhubungan dengan lingkaran hidup dan hari-hari besar keagamaan. Masyarakat Jawa beranggapan selamatan memiliki makna ataupun nilai-nilai religius dan sosial yang membangkitkan rasa solidaritas yang tinggi yakni kebersamaan, ketetanggaan, dan kerukunan sekaligus menimbulkan suatu perasaan yang kuat bahwa semua warga adalah sama derajatnya satu sama lain (Suseno, 2001:15).

Masyarakat Jawa memiliki pegangan hidup yang dapat digunakan untuk melaksanakan tradisi maupun dalam bertindak. Masyarakat selalu berpegangan pada filsafat hidupnya dan etika hidup agar selalu di jalan Tuhan dan untuk menghormati nenek moyang dan leluhur mereka. Menurut Mulder (1981:30), pandangan hidup masyarakat Jawa sangat menekankan pada ketentraman batin, keselarasan, dan keseimbangan, serta sikap menerima terhadap segala peristiwa yang terjadi. Hal tersebut menunjukkan bahwa setiap individu yang termasuk dalam bagian masyarakat Jawa memiliki tanggung jawab berupa hak dan kewajiban terhadap masyarakat, dan masyarakat mempunyai kewajiban terhadap alam. Oleh sebab itulah untuk menjaga ketentraman batin, keselarasan, dan keseimbangan masyarakat Jawa memiliki hak dan kewajiban untuk melaksanakan tradisi tersebut. Bagi masyarakat Jawa, upacara tradisi merupakan bagian dari siklus kehidupan manusia yang dilakukan untuk peristiwa-peristiwa yang tidak ditunjukan kepada kegiatan teknis sehari-hari, akan tetapi mempunyai kaitan dengan kepercayaan akan adanya kekuatan di luar kemampuan manusia.

Setiap kebiasaan yang dilakukan oleh manusia tidak terlepas dari makna atau nilai-nilai dalam sebuah simbol yang ada pada sebuah kebudayaan. Dari setiap makna tersebut sangat mempengaruhi tingkah laku dari pemiliki kebiasaan itu. Dalam proses komunikasi manusia, penyampaian pesan menggunakan bahasa, baik verbal maupun non verbal. Bahasa sendiri terdiri atas simbol-simbol yang mana simbol 
tersebut perlu dimaknai agar menjadi komunikasi yang efektif.

Simbol merupakan bentuk dari komunikasi nonverbal, dimana dari simbol tersebut ada makna yang mengandung pengertian-pengertian tertentu. Menurut Ismail (2007:8), bahwa simbol itu sendiri merupakan petunjuk untuk kita dapat membuat abstraksi. Dalam hal ini, simbol memiliki nilai instrumental atau alat ekspresi, komunikasi, pengetahuan, dan kontrol. Oleh karena itu, dilakukan upaya untuk mengkaji dan memahami makna dibalik simbolsimbol dalam sebuah tradisi yang harus dilakukan.

Masyarakat di Desa Medani memaknai tradisi Sedekah Bumi adalah tindakan manusia agar dapat bersinergi dengan alam dan lingkungannya, agar tercipta rasa aman, dan dijauhkan dari wabah penyakit. Kegiatan ini juga berdampak pada berbagai aspek kehidupan masyarakat, seperti aspek-aspek sosial, religi, seni, dan ekonomi. Dalam tradisi Sedekah Bumi, banyak mengandung nilai-nilai budaya luhur, sehingga sampai saat ini kegiatan tradisi Sedekah Bumi masih dilakukan secara turun-temurun oleh masyarakat pendukungnya. Nilai-nilai yang terkandung dalam ritual ini memiliki norma dan tata kelakuan yang dianggap baik untuk jadikan pedoman dalam bertindak dan berperilaku di masyarakat.

Salah satu upacara yang dilakukan oleh masyarakat Desa Medani Kecamatan Cluwak Kabupaten Pati adalah sedekah bumi. Pelaksanaan sedekah bumi di Desa Medani biasanya diadakan kondangan yang diadakan di punden atau keramat desa, kondangan yang ada di punden biasanya ada sesaji seperti ingkung, setelah melakukan kondangan biasanya diiringi tayub atau ledhek yang menyanyikan gending jawa dan selain itu ada juga kirab yang dilakukan di hari kedua.

Tradisi Sedekah bumi bukan hanya rutinitas atau ritual yang sifatnya tahunan. Akan tetapi tradisi sedekah bumi mempunyai makna yang lebih dari itu, upacara tradisional sedekah bumi itu sudah menjadi salah satu bagian dari masyarakat yang tidak akan mampu untuk dipisahkan dari budaya jawa . Pada acara upacara tradisi sedekah bumi tersebut 
umumnya, tidak banyak peristiwa dan kegiatan yang dilakukan di dalamnya. Hanya saja, pada waktu acara tersebut biasanya seluruh masyarakat sekitar yang merayakannya tradisi sedekah bumi membuat tumpeng dan berkumpul menjadi satu di tempat sesepuh kampung, di balai desa atau tempat tempat yang telah disepakati oleh seluruh masyarakat setempat untuk menggelar acara ritual sedekah bumi tersebut.

Setelah itu, kemudian masyarakat membawa tumpeng tersebut ke balai desa atau tempat setempat untuk didoakan oleh sesepuh adat. Kemudian kembali diserahkan kepada masyarakat setempat yang membuatnya sendiri. Nasi tumpeng kemudian dimakan secara (bersamasama) oleh masyarakat yang merayakan acara sedekah bumi itu. Namun, ada juga sebagian masyarakat yang membawa pulang nasi tumpeng tersebut untuk dimakan beserta sanak keluarganya di rumah masing-masing. Pembuatan nasi tumpeng ini merupakan salah satu syarat yang harus dilaksanakan pada saat upacara tradisi tradisional itu. Makanan yang menjadi makanan pokok yang harus ada dalam tradisi ritual sedekah bumi adalah nasi tumpeng dan ayam panggang. Sedangkan yang lainnya seperti minuman, buah-buahan dan lauk-pauk hanya bersifat tambahan saja, tidak menjadi perioritas yang utama. Pada acara akhir para petani biasanya menyisakan sebagian makanan itu dan diletakkan di sudutsudut petak sawahnya masing-masing sebagai bentuk Rasa Syukur.

Puncak acara ritual sedekah bumi di akhiri dengan melantunkan doa bersama-sama oleh masyarakat setempat dengan dipimpin oleh sesepuh adat. Doa dalam sedekah bumi tersebut umumnya dipimpin oleh sesepuh adat yang sudah sering dan terbiasa memimpin jalannya ritual tersebut. Ada yang sangat menarik dalam lantunan doa yang ada dilanjutkan dalam ritual tersebut. Yang menarik dalam lantunan doa tersebut adalah kolaborasi antara lantunan kalimat kalimat Jawa. Ritual sedekah bumi yang sudah menjadi rutinitas bagi masyarakat jawa ini merupakan salah satu jalan dan sebagai simbol penghormatan manusia terhadap tanah yang menjadi sumber kehidupan. 
Sebagian masyarakat belum mengetahui secara pasti makna kondangan seperti isi yang ada dalam kondangan yang dibawa ke punden dalam acara sedekah bumi di Desa Medani Kecamatan Cluwak Kabupaten Pati. Selain itu peneliti memperoleh informasi dari sesepuh Desa, bahwa masyarakat belum mengetahui makna dari kondangan dan tayub yang digunakan dalam acara di punden yang berada di Desa Medani Kecamatan Cluwak Kabupaten Pati.

Tayub dianggap sakral, kesenian ini dipercaya memberikan berkah kebahagiaan, oleh kerena itu jika tidak dilaksanakan akan terjadi musibah di wilayah tersebut. Selain itu penulis mendapatkan informasi dari Ketua Adat bahwa dalam pelaksanaan sedekah bumi ada kirab dengan membuat tiruan binatang untuk hiburan masyarakat. Terdapat hewan yang mitosnya tidak boleh dibuat sebagai tiruannya dan menjadi larangan keras dalam acara sedekah bumi seperti kuda dan harimau. Berdasarkan pada hal-hal tersebut di atas penulis tertarik untuk melakukan penelitian tentang makna simbolik tradisi sedekah bumi.

\section{METODE}

Dengan menggunakan pendekatan deskriptif kualitatif peneliti bermaksud untuk mendeskripsikan dan menjabarkan secara jelas, tentang makna simbolik Tradisi Sedekah Bumi Di Desa Medani Kecamatan Cluwak Kabupaten Pati yang menjadi sasaran penelitian, serta berusaha mengangkat realitas tersebut sebagai suatu sifat, ciri, karakter mengenai situasi, kondisi, maupun fenomena yang ada di dusun tersebut. Objek utama dalam penelitian ini adalah Tradisi Sedekah Bumi yang ada di Desa Medani. Semua hal yang berhubungan dengan Tradisi Sedekah Bumi di Desa Medani merupakan masalah yang menjadi bahasan peneliti. Penelitian ini juga bertujuan mencari data-data, informasi sehingga rumusan masalah yang telah peneliti ajukan dapat terjawab dan dapat diulas lebih dalam sehingga dapat diketahui maksud dari fenomena tersebut. 
Penelitian dilakukan pada bulan Juni sampai dengan September 2021, dalam rentang waktu tersebut peneliti melakukan proses observasi, wawancara, dan dokumentasi. Dalam penelitian ini peneliti menggunakan beberapa dokumen yaitu catatan lapangan, hasil wawancara, foto kegiatan pelaksaan tradisi Sedekah Bumi dan dokumen Desa tentang data monografi Desa Medani. Oleh karena itu, informan kunci dalam penelitian ini adalah orang-orang yang mengerti tentang tradisi Sedekah Bumi di Desa Medani, terdiri tokoh-tokoh masyarakat, Mbah Jarimin (Sesepuh Desa), Bapak Sudiro (kepala dusun), Bapak Kusno ( tokoh masyarakat) Desa Medani Kecamatan Cluwak Kabupaten Pati.

Pelaksanaan tradisi sedekah bumi ini dilaksanakan pada bulan apit dalam penanggalan Jawa, namun ketepatan pada bulan nasional dapat berubah-ubah. Dalam hal ini sulit sekali menentukan kapan akan dilaksanakannya tradisi ini, sehingga masyarakat memiliki patokan jika telah selesai masa panen baru diadakan Tradisi Sedekah Bumi.
Terdapat banyak ritual yang dijalankan dalam tradisi ini.

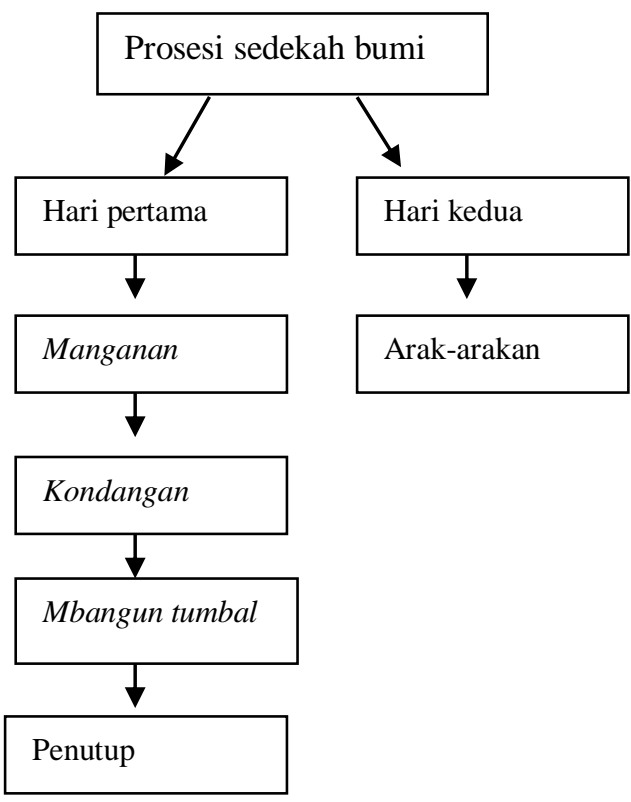

Gambar 1. Perayaan Sedekah Bumi

Perayaan sedekah bumi di hari pertama

1. Manganan

Ritual Sedekah Bumi yang pertama adalah manganan. Acara manganan sendiri adalah acara dimana seluruh warga desa berkumpul di makam untuk melaksanakan acara kenduren, dimana pada saat ritual ini seluruh masyarakat membawa nasi beserta lauk dan sayur yang akan digunakan untuk kenduren. Acara 
manganan ini dilaksanakan pada hari senin kliwon.

\section{Kondangan}

Kondangan adalah ritual dari pelaksanaan Tradisi Sedekah Bumi. Kondangan tidak diartikan sebagai nyumbang ke tempat tetangga namun kondangan disini sama halnya dengan kenduren. Kenduren dilakukan bersamaan dengan manganan di punden, kenduren yang dilakukan dipandu oleh Mbah Modin.

\section{Mbangun Tumbal}

Rangkaian acara yang ketiga adalah Mbangun Tumbal. Mbangun tumbal adalah acara yang dimaknai sebagai perubahan pondasi desa, memperbarui lagi pondasi desa, atau bisa disebut juga pagar desa.

4. Kesenian Tayub

Setelah melaksanakan serangkaian ritual acara selanjutnya adalah penampilan kesenian tayub. Kesenian tayub dimulai dengan persembahan tari gambyong oleh para sinden.

\section{Penutup}

Penutup merupakan ritual terakhir yang dilaksanakan dalam tradisi sedekah bumi, penutupan biasanya dilakukan pada pagi hari sekitar jam 10 pagi di tempat petinggi atau kepala desa. Penutupan dilakukan dengan kembali mempersembahkan kesenian tayub, dan di akhiri dengan kenduren bersama yang di pimpin oleh Mbah Modin Desa Medani.

\section{Perayaan sedekah bumi di hari kedua}

Perayaan sedekah bumi dilaksanakan hingga dua hari, Kirab atau Arak- arakan ini adalah acara sedekah bumi yang ke-dua, dimana acara tersebut diadakan hanya untuk bersenang-senang dan mempersembahkan hasil bumi yang sudah dihiasi dan di pawaikan mengelilingi desa.

\section{Makna Simbolik}

\section{Kondangan}

Kondangan adalah ritual dari pelaksanaan Tradisi Sedekah Bumi. Kondangan tidak diartikan sebagai nyumbang ke tempat tetangga namun kondangan disini sama halnya dengan kenduren. Kondangan yang dibawa kepunden ada nasi beserta lauk dari makanan yang dibawa kepunden tersebut, isi yang dibawa ada nasi kacang panjang yang sudah dimasak, 
daging ayam dan ikan, mie dan sate yang terdapat makna tersendiri, nasi disimbolkan sebagai tanah yang selama ini dapat kita tempati sedangkan lauk yang ada diatasnya seperti kacang panjang dimaknai sebagai keluarga yang awal mulanya satu keluarga dapat terpecah menjadi beberapa sedangkan daging ayam disimbolkan sebagai makhluk hidup yang ada dibumi,mie dilambangkan gelombang kehidupan dan sate adalah masyarakat. Walaupun sudah menjadi beberapa pecahan tetapi dapat disatukan seperti halnya masyarakat Desa Medani walaupun ada banyaknya masyarakat tapi dapat disatukan dengan acara yang dilaksanakan seperti sedekah bumi yang sudah menjadi ritual adat

\section{Tari ledek atau tayub}

Setelah melaksanakan serangkaian ritual acara selanjutnya adalah penampilan kesenian tayub. Kesenian tayub dimulai dengan persembahan tari gambyong oleh para sinden. Gambyong merupakan tarian pembuka yang dilakukan untuk membuka acara, tarian ini sering sekali digunakan pada acara Sedekah Bumi ataupun acara-acara lainnya.
Setelah itu Slereng, slereng adalah simbol yang digunakan untuk menghormati petinggi. Dimana sinden melantunkan tembang-tembang untuk menghibur petinggi, dan dilanjutkan dengan penampilan kesenian tayub yang disimbolkan guyub rukun masyarakat. Pelaksanaan kesenian bertujuan untuk bersenang-senang dan dipercaya bahwa tayub merupakan kesenian yang disenangi oleh Mbah Guru (danyang).

\section{Arak arakan}

Perayaan sedekah bumi dilaksanakan hingga dua hari, Kirab ini adalah acara sedekah bumi yang ke-dua, dimana acara tersebut diadakan hanya untuk bersenangsenang dan mempersembahkan hasil bumi yang sudah dihiasi dan di pawaikan mengelilingi desa.

Menurut sebagian masyarakat beranggapan bahwa jika diadakan pawai atau masyarakat desa medani menyebutnya dengan arakarakan, ada dua tiruan berbentuk binatang yang diyakini tidak boleh dibawa saat acara prosesi arak-arakan. hewan buatan tiruan berbentuk harimau (macan), dan kuda (jaran) diyakini akan membawa musibah jika 
tetap melanggar memngikutkan dalam prosesi arak-arakan tersebut.

Berdasarkan wawancara

dengan Bapak Kusno (45tahun), mengatakan bahwa tidak boleh dilanggar dikarenakan danyang (mbah guru) tidak suka jika ada yang menandingi atau merasa ditandingi dari hewan peliharaanya (Danyang). Selain itu masyarakat juga menghargai dari mbah Guru (Danyang) desa Medani.

\section{4. $\quad$ Prosesi Ritual Jembul Medani}

Upacara Jembul ini dimulai dengan mencuci kaki petinggi atau sekarang dikenal dengan kepala desa dengan kembang setaman. Aktivitas ini dilakukan oleh perangkat desa, sebagai perlambang kepada Danyang. Pada masa sekarang masyarakat lebih memaknai sebagai bentuk permohonan agar tercipta kehidupan yang tenteram, bersih dari malapetaka dan segala kesulitan yang menimpa penduduk. Di samping itu sekaligus untuk mengingatkan kepada petinggi agar selalu bersih dalam segala tindakan, dan langkahnya tidak melanggar larangan-larangan agama, larangan pemerintah, serta menerapkan asas kejujuran dan keadilan dalam memimpin masyarakat desa medani.

Setelah pencucian kaki petinggi, maka dilakukan selamatan sebagai lambang permohonan kepada Tuhan Yang Maha Esa agar Desa medani tetap selamat sentosa dan hasil bumi pada tahun mendatang melimpah ruah sehingga kehidupan penduduk desa medani menjadi sejahtera, cukup sandang, pangan dan papan. Acara mengitari Jembul sebanyak tiga kali merupakan inti dari proses Jembul. Kegiatan mengitari Jembul dilakukan oleh petinggi diikuti oleh ledek atau penari tayub dan para perangkat desa. Prosesi ini dilakukan untuk melakukan pemeriksaan terhadap para nayoko projo yang datang menghadap dia sekaligus untuk menyerahkan hulu bekti yang dibawanya. Kesetiaan para nayoko projo ini pada masa sekarang lebih diartikan sebagai pengingat-ingat agar para pemimpin desa medani selalu menyempatkan diri untuk memberikan perhatian pada staf perangkat desanya dalam menjalankan tugas sehari-hari. 
a. Makna Simbolik Ritual Jembul

\section{Medani}

Upacara ritual diadakan oleh masyarakat sebagai rasa syukur terhadap Tuhan dan untuk mengenang jasa roh leluhur, serta sebagai saran asosialisasi pengukuhan nilai-nilai budaya yang sudah ada dalam kehidupan seharihari. Pelaksanaan Ritual Jembul memiliki berbagai makna simbolik antara lain, Simbol persaudaraan dan kebersamaan serta keihlasan yang terkandung dalam proses pesiapan keperluan pelaksanaan tradisi dan juga pembagian tugas untuk mempersiapkan perlengkapan dan keperluan tradisi seperti pada pembuatan Jembul dan persiapan berbagai macam perlengkapan lainnya. Warga masyarakat Medani bersama-sama mempersiapkan segala kebutuhan untuk pelaksanaan upacara Jembul, berkumpul bersama mengadakan rapat untuk pembagian tugas masing-masing.

Dalam hal ini suksesnya pelaksanaan tradisi adalah eratnya rasa persaudaraan, kebersamaan serta rasa ikhlas dalam menyelesaikan tugas sehingga menghasilkan kerjasama dan hasil yang baik. Selain itu juga mengumpulkan dana bersama untuk pelaksanaan upacara juga bagian dari symbol keikhlasan dalam menyelesaikan pekerjaan. Didalam jembul berisi beberapa makanan seperti jadah tape dan pisang sebagai simbol kebersamaan masyarakat seperti perbedaan yang ada dalam satu wadah tetapi tetap tentram dan saling menghargai satu sama lain. Juga symbol penghormatan dan kedudukan terkandung dalam prosesi mencuci kaki Kepala Desa atau Petinggi, yaitu para perangkat desa dan masyarakat mendatangi rumah kepala desa untuk mencuci kakinya. Hal tersebut merupakan bentuk interaksi yang menyimbulkan rasa hormat masyarakat Desa Medani terhadap ketua mereka. Pada prosesi Jembul yang menjadi pemimpin ritual dan pembacaan doa dan mantra adalah tokoh masyarakat desa Medani yang paling tua umurnya menyimbolkan sikap penghormatan terhadap orang yang lebih tua, serta symbol kedudukan seseorang itu akan 
menentukan peranannya, yaitu seseorang harus menjalankan perannya sesuai dengan kedudukan yang ia miliki. Simbol keindahan, keselarasan serta kreativitas tercermin dari tarian, tayub yang mereka tampilkan dalam pelaksanaan ritual, menampilkan keindahan-keindahan serta keselarasan dari kreativitas seni yang mereka ciptakan. Simbol keyakinan dan kepercayaan dan penghargaan terkandung dalam pembacaan doa-doa dalam ritual Jembul serta pemberian sesaji dalam acara manganan di punden merupakan symbol permohonan izin kepada cikal bakal dan meminta berkah dari sang leluhur termasuk juga dalam symbol penghargaan terhadap para leluhur yang telah mewariskan mereka tradisi Jembul tersebut.

Simbol persaudaraan dan kerja sama terkandung dalam proses pesiapan keperluan pelaksanaan tradisi serta pembagian tugas untuk mempersiapkan perlengkapan dimaknai oleh warga masyarakat Medani sebagai pesan bahwa di dalam kehidupan yang dijalani serta menurut ajaran agama yang mereka anut mengharuskan mereka agar selalu menjaga tali persaudaraan terhadap sesama dan tidak boleh sampai memutuskannya. Keyakinan-keyakinan tersebut tidaklah terjadi begitu saja, akan tetapi muncul dari hasil interaksi antar sesama. Begitu juga dengan kerjasama, pemahaman mereka tentang symbol kerjasama didapatkan dari pengalaman mereka dalam kehidupan sehari-hari dalam mengerjakan suatu pekerjaan besar tanpa kerjasama yang baik akan terasa berat dan mendapat hasil yang tidak baik, sebaliknya akan menjadi ringan jika dilakukan bersama.

\section{b. Sego buceng (nasi tumpeng)}

Nasi buceng memiliki bentuk segitiga yang merucut keatas, hal ini dilambangkan dengan wujud syukur dan sembah bakti atau juga simbol penghormatan kepada yang maha kuasa. Tumpeng atau buceng ini diberikan cabai, bawang merah, atau pun terasi hal ini memiliki makna bahwa itu adalah hasil dari bumi. Isi dari buceng memiliki makna tersendi seperti telur sebagai 
lambang kehidupan, buceng dari kata nyebuto sing kenceng artinya jika seseorang sedang mendapatkan cobaan seharusnya intropeksi diri, dan arti dari bawang merah dan cabai dimaknai sebagai yang maha kuasa agar kita selalu ingat kepada Tuhan.

Penghormatan dan rasa
syukur kepada yang maha kuasa
atas berkah limpahan hasil bumi.
Begitu pula dengan lauk pauk yang ada sebagai pelengkap mencerminkan hasil bumi yang di dapat di Desa Medani.

\section{c. ingkung}

Ingkung adalah makanan yang berbahan dasar ayam yang dimasak secara utuh, Ayam ingkung adalah yang berasal dari kata manengkung dalam bahasa jawa kuno yang memiliki arti memanjat doa kepada Tuhan Yang Maha Esa dengan hati yang sungguh-sungguh makanan yang dipergunakan untuk sesaji dalam upacara tradisi yang dilakukan untuk menghormati, memuja, mensyukuri dan meminta keselamatan pada leluhur yang merupakan pencerminan semua perencanaan dan tindakan yang diatur dalam tata nilai luhur dan diwariskan secara turun-temur.

$$
\text { Dalam pelaksanaannya }
$$

upacara adat dilakukan secara bersama-sama di dalam lingkungan masyarakat, mulai dari persiapan hingga pelaksanaan upacara, di masyarakat desa medani ingkung dimaknai simbol sebagai manusia dan telur sebagai kelahiran maka sebelum meninggal dunia sebaiknya membersikan diri. Membersihkan diri bukan berarti mandi atau membersihkan kotoran atau debu yang ada dibadan. Tetapi bertindak dengan baik dengan menjalankan ajaran agama kita masing-masing agar tidak melakukan perbuatan yang tercela yang menimbulkan kebencian terhadap sesama makhluk lain atau menyebabkan dosa.

\section{KESIMPULAN}

Berdasarkan hasil penelitian di atas dapat diketahui bahwa tradisi sedekah bumi di desa medani Kecamatan Cluwak Kabupaten Pati bahwa prosesi tradisi sedekah bumi sudah dilaksanakan secara turun temurun dilaksanakan pada bulan Apit pada penanggalan jawa. Dalam prosesi 
sedekah bumi terdapat beberapa acara yaitu pelaksanaan ritual dan arakarakan. Adapun dalam pelaksanaan sedekah bumi masyarakat membawa hasil bumi sebagai pertanda wujud rasa syukur atas limpahan nikmat yang telah diberikan dan membawa penghidupan bagi mereka selama ini. Prosesi sedekah bumi memiliki ritual manganan dan masyarakat membawa makanan sebagai simbol rasa syukur dan dan dipercaya makanan yang sudah dibacakan do'a dapat membuat tanaman terhindar dari penyakit atau hama, sedangkan hasil bumi yang dibawa saat prosesi arak-arakan disimbolkan rasa syukur atas limpahan hasil bumi dari yang maha kuasa.

\section{DAFTAR PUSTAKA}

Abdurrohman, M. (2016). Memahami Makna-Makna Simbolik pada Upacara Adat Sedekah Laut di Desa anjungan Kecamatan Kragan Kabupaten Rembang. Jurnal The Messenger 7: (1), 27 34.

Ismail, Arifuddin. 2007. Religi Manusia Nelayan Masyarakat Mandar. Makassar: CV Indobis rekagrafis.

Mulyana, Deddy. (2008). Metodologi Penelitian Kualitatif Paradigma Baru Ilmu Komunikasi dan Sosial Lainnya. Bandung: PT. Remaja Rosda Karya.

Mulder, Niels. (1981). Kepribadian Jawa Dan Pembangunan Nasional. Yogyakarta: Gajah Mada University Press

Mugiyo. (2020). Nyadran kali dalam perspektif buddhisme. Jurnal pariwisata dan budaya. Vol.01 no.01 